\title{
PENGARUH PEMBERIAN EKSTRAK KACANG HIJAU TERHADAP KADAR KOLESTROL TOTAL PADA WANITA HIPERKOLESTEROLEMIA
}

\author{
Ika Wati Sulistyaningsih, Tatik Mulyati ${ }^{*}$ \\ Program Studi Ilmu Gizi Fakultas Kedokteran Universitas Diponegoro \\ Jl.Dr.Sutomo No.18, Semarang, Telp (024) 8453708, Email : gizifk@undip.ac.id
}

\begin{abstract}
Background: Increase of total cholesterol level is associated with atherosclerosis that is the one of risk factor heart and cardiovascular disease. Isoflavones is the one kind of flavonoid and water soluble fiber found in mung bean can regulate lipogenesis in liver by increasing the catabolism of lipid cells to form energy and the fiber bind lipid in intestine to reduce total cholesterol levels.

Objective: To determine the effect of $75 \mathrm{~g}$ mung bean extract on total cholesterol to woman with hypercolesterolemia. Methods: This reseach was true experimental study with pre-post control group design. Subjects were 30 womens with total cholesterol level $\geq 200 \mathrm{mg} / \mathrm{dl}$, classified into 2 group, control group got placebo and the treatment group consumed mung bean extract $75 \mathrm{~g} /$ day. Intervention was done for 14 days. Serum total cholesterol level was measured with CHOD-PAP method. Shapiro Wilk was used to analyze normality of the data. The statistical analyize used pairedt test, Wilcoxon, independent t-test and Mann-Whitney.

Results: Mean of total cholesterol before and after intervention in treatment group is 238,13 mg/dl and $217 \mathrm{mg} / \mathrm{dl}$. There were difference of total cholesterol level before and after intervention $(p=0,031)$. The Mean of total cholesterol level before and after intervention in control group is 243,07 $\mathrm{mg} / \mathrm{dl}$ and 241,47 $\mathrm{mg} / \mathrm{dl}$. There were no difference of total cholesterol level before and after in control group $(p=0,704)$.

Conclusion: Consumption of extract mung bean 75 g/day effective to reduced total cholesterol level in woman with hypercholesterolemia.
\end{abstract}

Key word: Mung beans; total cholesterol; woman; hypercholesterolemia

\begin{abstract}
ABSTRAK
Latar Belakang: Peningkatan kadar kolesterol total diduga berhubungan dengan terjadinya aterosklerosis yang menjadi salah satu faktor risiko penyakit jantung dan kardiovaskuler. Isoflavon merupakan jenis flavonoid dan serat larut air yang terdapat di kacang hijau dapat mengatur lipogenesis di hati dengan cara meningkatkan katabolisme sel lemak dalam pembentukan energi dan seratnya mengikat lemak di dalam usus serta mengakibatkan turunnya kadar kolesterol total.

Tujuan: Mengetahui pengaruh ekstrak kacang hijau sebanyak 75 g terhadap kadar kolesterol total pada wanita hiperkolesterolemia.

Metode: Jenis penelitian adalah true experimental dengan rancangan pre-post control group design. Subyek penelitian adalah 30 wanita dengan kadar kolesterol total $\geq 200 \mathrm{mg} / \mathrm{dl}$, dibagi menjadi 2 kelompok, yaitu kelompok kontrol mendapat plasebo dan kelompok perlakuan diberi ekstrak kacang hijau sebanyak 75 g/hari. Intervensi dilakukan sel ama 14 hari. Metode CHOD-PAP digunakan untuk menganalisis kadar kolesterol total. Uji normalitas menggunakan Shapiro Wilk. Analisis statistik menggunakan uji paired sample t-test, Wilcoxon, independent t-test dan Mann-Whitney.

Hasil: Rerata kadar kolesterol sebelum dan sesudah intervensi pada kelompok perlakuan adalah 238,13 mg/dl dan $217 \mathrm{mg} / \mathrm{dl}$. Terdapat perbedaan kadar kolesterol sebelum dan sesudah intervensi pada kelompok perlakuan ( $p=0,031)$. Rerata kadar kolesterol total sebelum dan sesudah intervensi pada kelompok kontrol adalah 243,07 mg/dl dan 241,47 mg/dl. Tidak terdapat perbedaan kadar kolesterol total sebelum dan sesudah pada kelompok kontrol $(p=0,704)$.
\end{abstract}

Kesimpulan: Pemberian ekstrak kacang hijau sebanyak 75 g/hari berpengaruh terhadap penurunan kadar kolesterol total secara bermakna pada wanita hiperkolesterolemia.

Kata kunci: Kacang hijau; kolesterol total; wanita; hiperkolesterolemia.

\section{PENDAHULUAN}

Hiperkolesterolemia merupakan suatu keadaan peningkatan kadar kolesterol total $\geq 200$ $\mathrm{mg} / \mathrm{dl}$ dan mempunyai hubungan yang erat dengan keparahan aterosklerosis atau timbulnya lemak di saluran pembuluh darah yang menjadi salah satu faktor terjadinya penyakit jantung dan kardiovaskuler. ${ }^{1}$ Riset Kesehatan Dasar (RISKESDAS) tahun 2007 prevalensi penyakit jantung sebesar $7,2 \%$ dan terjadi peningkatan di tahun 2013 menjadi 7,5\%.,2,3 Jumlah kasus penyakit jantung dan pembuluh darah pada tahun $2012 \mathrm{di}$ Jawa Tengah terdapat 806.208 kasus. $^{4}$ 
Wanita merupakan kelompok yang paling banyak dijumpai menderita penyakit metabolisme lemak. Sebuah survey yang dilakukan di Jerman pada tahun 2008-2011 menyatakan bahwa 65,7\% responden wanita menderita dislipidemia. ${ }^{5}$ Selain itu, sebuah studi meta-analisis lainnya pada tahun 2013 di Iran menyatakan prevalensi hiperkolesterolemia pada wanita lebih tinggi sebesar $41,8 \%$ dibandingkan pria sebesar 38,9\%. ${ }^{6}$

Faktor risiko terjadinya peningkatan kadar kolesterol antara lain konsumsi makanan yang mengandung tinggi lemak, kebiasaan merokok, hipertensi, kelebihan berat badan, peningkatan kadar kolesterol LDL (Low Density Lipoprotein) dan penurunan kadar kolesterol HDL (High Density Lipoprotein) pada orang dewasa 35 tahun ke atas. ${ }^{7,8}$ Selain itu, terdapat juga faktor risiko yang tidak dapat dikendalikan meliputi usia, jenis kelamin, dan keturunan. Diabetes melitus dan hiperlipidemia juga menjadi faktor risiko terjadinya penyakit jantung koroner. ${ }^{9}$

Faktor-faktor yang dapat menurunkan kadar kolesterol adalah mengurangi asupan lemak dan kolesterol, olahraga teratur dan memilih makanan yang dapat menurunkan kolesterol salah satunya adalah bahan makanan yang mengandung isoflavon. ${ }^{10,11}$ Isoflavon merupakan salah satu jenis flavonoid yang terbukti dapat mengatur lipogenesis di hati. Isoflavon jenis genistein dan deidzein banyak terdapat dalam kacang-kacangan seperti kacang hijau dan kacang kedelai. ${ }^{12}$

Genistein dapat menghambat produksi hidrogen peroksida dan meningkatkan aktivitas enzim antioksidan, seperti katalase, peroksida dismutase, glutation peroksidase, dan glutation reduktase. LDL yang berinteraksi dengan isoflavon akan terjadi penurunan oksidasi lipoprotein dan menekan pembentukan lipid peroksida dan zat-zat reaktif asam tiobarbiturat. Mekanisme penurunan kadar kolesterol oleh isoflavon dengan meningkatkan katabolisme sel lemak dalam pembentukan energi yang mengakibatkan turunnya kadar kolesterol total. ${ }^{12,13,14}$ Penelitian yang dilakukan oleh Mochtar IY et al menyatakan bahwa asupan isoflavon sebanyak 2,5 atau $5 \mathrm{mg} / \mathrm{kgBB}$ pada kelinci jantan dapat menurun kadar kolesterol total sebanyak $19,7 \%$ dan $20,4 \% .^{15}$

Kacang hijau adalah salah satu jenis kacangkacangan yang banyak terdapat di Indonesia dan menjadi makanan selingan atau sebagai minuman. Kandungan gizi kacang hijau dalam 100 gr bahan memiliki energi sebesar $323 \mathrm{kkal}$, protein sebesar 22,9 gr, lemak 1,5 gr, serat sebesar 7,6 gr, dan isoflavon sebesar 4,3 gr/100 gr. ${ }^{16,17}$ Jenis serat yang terdapat dalam kacang hijau adalah serat larut air yang mengikat lemak di dalam usus, sehingga dapat menurunkan kadar kolesterol darah sampai 5\% atau lebih. ${ }^{18}$

Kandungan lemak dalam kacang hijau adalah $1,3 \%$ dibawah kedelai $18 \%$ yang menyebabkan kacang hijau tidak mudah tengik. Berdasarkan kandungan lemak kacang hijau tersebut, 73\% diantaranya merupakan asam lemak tak jenuh dan $26 \%$ tersusun atas lemak jenuh sehingga aman untuk dikonsumsi pada orang dengan kelebihan berat badan dan penderita penyakit jantung. ${ }^{19}$

Penelitian yang dilakukan oleh Novi $\mathrm{C}$ dan Enny $\mathrm{P}$ tentang pemberian ekstrak kacang hijau selama 14 hari pada serum tikus hiperkolestrolemia dengan dosis $0,45 \mathrm{gr} / \mathrm{kgBB}$ dan $1,35 \mathrm{gr} / \mathrm{kgBB}$ mengandung isoflavon sebesar $70,74 \mathrm{mg}$ per $100 \mathrm{gr}$ bahan dapat menurunkan kadar kolesterol LDL sebesar $21,06 \%$ walaupun secara statistik tidak bermakna. ${ }^{20} \mathrm{Hal}$ ini mendorong peneliti untuk mengkaji tentang pemberian ekstrak kacang hijau terhadap kadar kolesterol total pada wanita hiperkolesterolemia.

\section{METODE}

Penelitian ini merupakan penelitian true experimental dengan rancangan pre-post control group design. Variabel terikat dalam penelitian ini adalah kadar kolesterol total penderita hiperkolesterolemia, sedangkan variabel bebas adalah ekstrak kacang hijau.

Subyek penelitian merupakan karyawati kantor Badan Pusat Statistik Jawa Tengah, Dinas Perindustrian dan Perdagangan Jawa Tengah, serta Dinas Pendidikan Jawa Tengah. Kriteria inklusi memiliki kadar kolesterol $\geq 200 \mathrm{mg} / \mathrm{dl}$, belum menopause, tidak dalam keadaan hamil atau menyusui, indeks massa tubuh (IMT) tidak lebih dari $30 \mathrm{~kg} / \mathrm{m}^{2}$, tidak sedang mengkonsumsi obat antihiperkolesterolemia, dan tidak sedang perawatan dokter. Penentuan IMT tidak lebih dari $30 \mathrm{~kg} / \mathrm{m}^{2}$ karna penurunan kadar kolesterol pada seseorang dengan IMT $>30 \mathrm{~kg} / \mathrm{m}^{2}$ juga harus disertai dengan penurunan berat badan dan modifikasi diet. ${ }^{21}$ Perhitungan subyek penelitian menggunakan rumus uji hipotesis terhadap rerata dua populasi independen dan dibutuhkan sebanyak 30 subyek.

Penentuan subyek penelitian menggunakan metode consecutive sampling. Sebanyak 88 orang bersedia diambil darahnya untuk proses skrining awal. Sebanyak 34 orang memenuhi kriteria inklusi untuk menjadi subyek penelitian. Selama proses intervensi terdapat 4 subyek yang mengalami drop out karena mengundurkan diri, sehingga jumlah subyek manjadi 30 orang. Subyek dibagi menjadi 2 
kelompok dengan metode simple ramdom sampling, yang terdiri dari satu kelompok kontrol dan satu kelompok perlakuan, masing-masing kelompok terdiri atas 15 orang. Kelompok kontrol diberikan plasebo yaitu air sirup rendah kalori dan kelompok perlakuan diberikan ekstrak kacang hijau sebanyak $75 \mathrm{~g} /$ hari sebagai pengganti lauk nabati yang diberikan 2 kali sehari yaitu jam 10.00 wib dan jam 15.00 wib bentuk minuman kemasan@ 200 $\mathrm{ml}$.

Pembuatan ekstrak kacang hijau dengan cara menimbang kacang hijau sebanyak 37,5 gr terlebih dahulu, direndam dengan air sebanyak $\pm 400 \mathrm{ml}$ selama 12 jam kemudian direbus selama 30 menit hingga lunak, sesudah lunak kacang hijau di haluskan dengan blender dan dilakukan penyaringan. Selanjutnya dikemas kedalam botol ukuran $200 \mathrm{ml}$ dan ditambahkan gula rendah kalori $2,5 \mathrm{gr} /$ kemasan yang diberikan 2 kali sehari. Placebo dibuat dengan mengemas air sirup rendah kalori yang diberikan 2 kali sehari dalam botol ukuran $200 \mathrm{ml}$.

Pemberian ekstrak kacang hijau dan plasebo dilakukan selama 14 hari. Asupan sehari kelompok kontrol tidak dikontrol dan dibiarkan sebagaimana biasa, sedangkan kelompok perlakuan tidak mengkonsumsi makanan sumber protein nabati selama intervensi. Pencatatan makanan dilakukan sebelum sebanyak 2 kali dan selama intervensi sebanyak 14 kali dengan menggunakan recall 24 jam. Kepatuhan mengkonsumsi ekstrak kacang hijau dikontrol dengan menggunakan formulir daya terima.

Kadar kolesterol total dianalisis dengan pemeriksaan laboratorium menggunakan metode CHOD-PAP (Cholesterol Oxidase Paraoxidase Aminophenazone). Darah diambil oleh petugas laboratorium. Pengambilan darah dilakukan sebelum dan sesudah intervensi. Data asupan makan subyek menggunakan program nutrisurvey 2005.

Karakteristik subyek serta asupan makan subyek sebelum dan selama penelitian dilakukan dengan menggunakan analisis deskriptif. Data yang diperoleh diuji normalitasnya dengan uji Shapirowilk. Perbedaan kadar kolestrol total sebelum dan sesudah intervensi dilakukan uji paired t-test karena data berdistribusi normal. Perbedaan pengaruh perlakuan kedua kelompok dilakukan uji MannWhitney karena data berdistribusi tidak normal dan untuk data berdistribusi normal menggunakan uji independent $t$-test.

\section{HASIL PENELITIAN \\ Karakteristik subyek}

Karakteristik subyek terdiri dari gambaran umur dan status gizi subyek sebelum penelitian disajikan dalam tabel 1 .

Tabel 1. Deskripsi Karakteristik Tiap Kelompok

\begin{tabular}{|c|c|c|c|c|c|c|c|}
\hline \multirow[t]{2}{*}{ Karakteristik subyek } & \multirow[t]{2}{*}{ Mean \pm SD } & \multicolumn{2}{|c|}{$\begin{array}{c}\text { Kontrol } \\
(n=15)\end{array}$} & \multirow[t]{2}{*}{ Mean \pm SD } & \multicolumn{2}{|c|}{$\begin{array}{c}\text { Perlakuan } \\
(n=15)\end{array}$} & \multirow[t]{2}{*}{$\mathbf{p}$} \\
\hline & & $\mathbf{N}$ & $\%$ & & $\mathbf{N}$ & $\%$ & \\
\hline Usia & & & & & & & $0.078^{1}$ \\
\hline 20-29 tahun & & 3 & 20 & & 1 & 6.7 & \\
\hline 30-39 tahun & $43 \pm 6.07$ & 5 & 33.3 & $38.13 \pm 8,23$ & 3 & 20 & \\
\hline 40-49 tahun & & 6 & 40 & & 9 & 60 & \\
\hline 50-59 tahun & & 1 & 6.7 & & 2 & 13.3 & \\
\hline Status gizi ${ }^{22}$ & & & & & & & $0.652^{1}$ \\
\hline Normal $\left(18,5-22,9 \mathrm{~kg} / \mathrm{m}^{2}\right)$ & & 3 & 20 & & 2 & 13.3 & \\
\hline Overweight $\left(23-24,9 \mathrm{~kg} / \mathrm{m}^{2}\right)$ & $25,5 / \pm 2.02$ & 3 & 20 & $26 \pm 3,05$ & 3 & 20 & \\
\hline $\operatorname{Obesitas}\left(\geq 25 \mathrm{~kg} / \mathrm{m}^{2}\right)$ & & 9 & 60 & & 10 & 66.7 & \\
\hline $\begin{array}{l}\text { Kolesterol total sebelum } \\
\text { penelitian }\end{array}$ & $243.07 \pm 28,17$ & & & $238.13 \pm 32.43$ & & & $0,468^{2}$ \\
\hline
\end{tabular}

${ }^{1}$ uji beda independent t-test

${ }^{2}$ uji beda mann-whitney

Sebagian besar subyek berada pada kelompok umur 40-49 baik pada kelompok kontrol (40\%) dan perlakuan (60\%). Hasil uji beda menunjukkan tidak terdapat perbedaan umur terhadap kedua kelompok $(p>0,05)$. Status gizi sebagian besar berada pada kategori obesitas baik pada kelompok kontrol $(66,7 \%)$ dan perlakuan $(60 \%)$. Hasil uji beda menunjukkan tidak terdapat perbedaan status gizi terhadap kedua kelompok ( $>0,05$ ). Tidak terdapat perbedaan kadar kolesterol total pada kelompok kontrol dan perlakuan.

Perbedaan dan perubahan asupan makan sebelum dan selama intervensi

Perbedaan dan perubahan asupan makan subyek sebelum dan selama intervensi antara kedua kelompok disajikan dalam tabel 2. 
Tabel 2. Perbedaan dan perubahan asupan sebelum dan sesudah intervensi

\begin{tabular}{llll}
\hline Asupan & $\begin{array}{l}\text { Kontrol }(\mathbf{n}=\mathbf{1 5}) \\
\text { Mean } \pm \text { SD }\end{array}$ & $\begin{array}{l}\text { Perlakuan }(\mathbf{n}=\mathbf{1 5}) \\
\text { Mean } \pm \text { SD }\end{array}$ & $\mathbf{p}$ \\
\hline Energi pre & $1595.7 \pm 282.37$ & $1611.5 \pm 358.19$ & $0.063^{3}$ \\
Energi post & $1625 \pm 192.52$ & $1707.1 \pm 252.79$ & \\
$\Delta$ energi & $29.34 \pm 215.82$ & $183.73 \pm 221.16$ & \\
p & $0.607^{1}$ & $0.095^{1}$ & \\
\hline Protein pre & $57.68 \pm 18.16$ & $56.3 \pm 16.33$ & $0.053^{3}$ \\
Protein post & $60.96 \pm 13.99$ & $65.03 \pm 13.04$ & \\
$\Delta$ protein & $3.28 \pm 15.27$ & $11.3 \pm 19.78$ & \\
p & $0.281^{2}$ & $0.099^{2}$ & $0.967^{4}$ \\
\hline Karbohidrat pre & $219.68 \pm 45.65$ & $218.17 \pm 65.05$ & \\
Karbohidrat post & $231.92 \pm 36.92$ & $227.35 \pm 54.91$ & \\
$\Delta$ karbohidrat & $12.10 \pm 34.88$ & $9.18 \pm 34.93$ & \\
p & $0.015^{2}$ & $0.281^{2}$ & \\
\hline Lemak pre & $51.89 \pm 17.83$ & $49.0 \pm 18.74$ \\
Lemak post & $51.35 \pm 12.29$ & $48.78 \pm 12.22$ & \\
$\Delta$ lemak & $-0,55 \pm 19.02$ & $-0.78 \pm 19.28$ & \\
p & $0.913^{2}$ & $0.878^{2}$ & \\
\hline Serat pre & $12.69 \pm 4.75$ & $11.75 \pm 4.10$ & \\
Serat post & $12.03 \pm 2.94$ & $17.53 \pm 4.87$ & \\
$\Delta$ serat & $-0.66 \pm 4.57$ & $5.77 \pm 5.48$ & \\
p & $0.649^{2}$ & $0.001^{2}$ & \\
\hline Kolesterol pre & $262.44 \pm 120.48$ & $232.87 \pm 139.52$ & \\
Kolesterol post & $260.55 \pm 127.77$ & $233.18 \pm 67.77$ & \\
$\Delta$ kolesterol & $-1.89 \pm 15.76$ & $0.31 \pm 146.01$ & \\
p & $0.988^{1}$ & $0.993^{1}$ & \\
\hline
\end{tabular}

${ }^{1}$ uji paired sample t-test ${ }^{2}$ uji wilcoxon

${ }^{3}$ uji independent t-test ${ }^{4}$ uji mann-whitney

Berdasarkan tabel 2, terdapat perbedaan asupan serat sebelum dan sesudah intervensi antara kelompok kontrol dan perlakuan $(\mathrm{p}<0,05)$. Pada kelompok perlakuan terdapat perbedaan serat sebelum dan sesudah intervensi $(\mathrm{p}<0,05)$ dan pada kelompok kontrol terdapat perbedaan pada asupan karbohidrat sebelum dan sesudah intervensi $(\mathrm{p}<0,05)$.

Perbedaan kategori status gizi sebelum dan sesudah intervensi

Perbedaan kategori status gizi sebelum dan sesudah intervensi disajikan pada diagram 1.

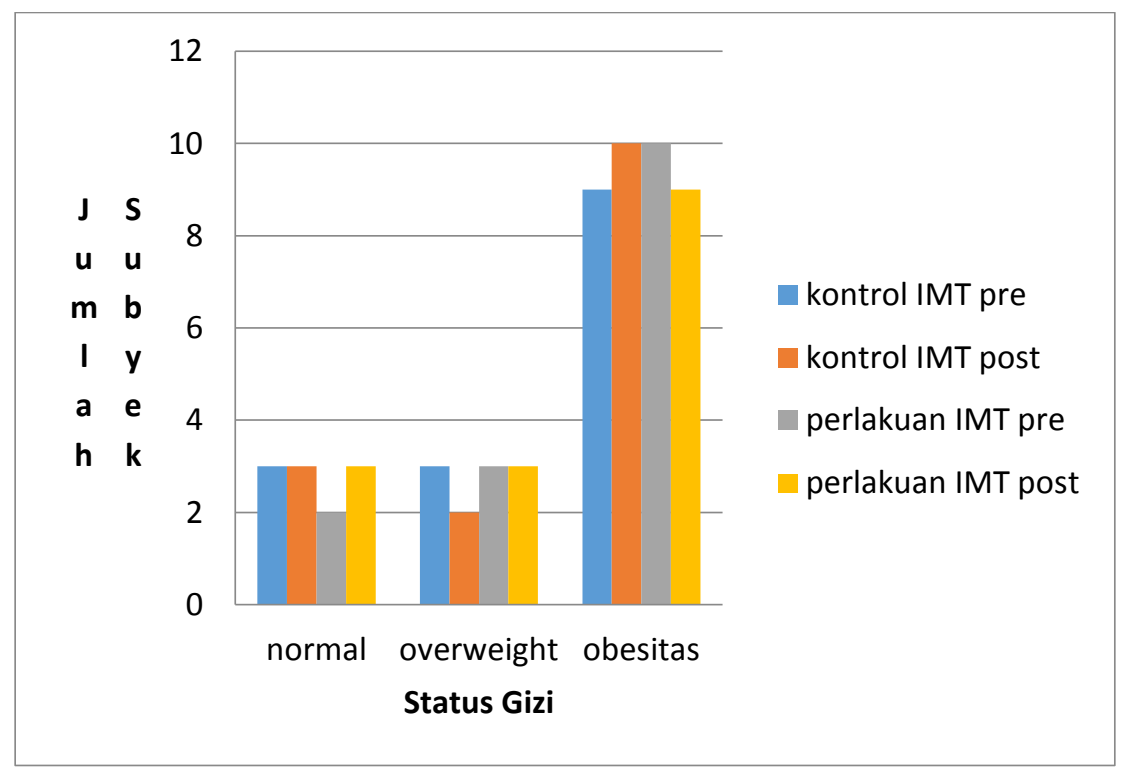

${ }^{1}$ uji paired t-test

Diagram 1. Perbedaan status gizi sebelum dan sesudah intervensi, $p=0,144(p>0,05)$ 
Diagram 1 menunjukkan tidak terdapat perubahan status gizi sebelum dan sesudah intervensi antara kedua kelompok ( $p>0.05)$.

\section{Perbedaan kadar kolesterol total sebelum dan sesudah intervensi}

Perbedaan kadar kolesterol total sebelum dan sesudah intervensi disajikan pada tabel 3 .

Tabel 3. Perbedaan kadar kolesterol total sebelum dan sesudah intervensi

\begin{tabular}{llll}
\hline Variabel & Kontrol & Perlakuan & p \\
\cline { 2 - 3 } & mean \pm SD & mean \pm SD & \\
\hline Kolesterol total $(\mathrm{mg} / \mathrm{dl})$ & & & \\
Pre & $243.07 \pm 28.17$ & $238.13 \pm 32.43$ & $0,468^{4}$ \\
Post & $241.47 \pm 31.38$ & $217.0 \pm 38.6$ & $0,67^{3}$ \\
$\Delta$ & $-1,6 \pm 16.01$ & $-21.13 \pm 34.22$ & $0,115^{4}$ \\
$\mathrm{p}$ & $0.704^{1}$ & $0.031^{1}$ & \\
\hline
\end{tabular}

${ }^{1}$ uji paired sample t-test ${ }^{2}$ uji wilcoxon

${ }^{3}$ uji independen t-test ${ }^{4}$ uji mann-whitney

Pada tabel 3, menunjukkan bahwa tidak terdapat perbedaan kadar kolesterol total pada kedua kelompok ( $>>0,05)$. Pada kelompok perlakuan terdapat perbedaan kolesterol total sebelum dan sesudah intervensi $(\mathrm{p}<0,05)$.

\section{PEMBAHASAN}

Karakteristik subyek dalam penelitian ini adalah wanita hiperkolesterolemia dan belum mengalami menopause. Sebagian besar subyek berusia 40-49 tahun, dan rerata subyek sebagian besar termasuk ke dalam kategori obesitas. Hasil uji statistik menunjukkan tidak terdapat perbedaan umur maupun status gizi pada kelompok kontrol dan perlakuan, begitu pula dengan kadar kolesterol total sebelum dilakukan intervensi. Sehingga dapat disimpulkan karakteristik subyek pada awal penelitian tergolong homogen.

Umur 20-50 tahun terjadi penambahan berat badan dan secara bersamaan juga terjadi peningkatan kadar kolesterol. ${ }^{23}$ Penelitian yang dilakukan oleh Galman menunjukkan bahwa terdapat hubungan antara kadar kolesterol total dengan pertambahan usia pada tikus. Peningkatan kadar kolesterol darah dengan pertambahan usia berhubungan dengan eliminasi kolesterol sebagai garam empedu dan penurunan reseptor yang memediasi clearence dari LDL plasma. Wanita pada usia subur terlindungi oleh hormon estrogen yang berperan dalam mencegah terjadinya plak arteri. $^{24}$ Wanita yang memasuki masa pre menopause hingga menopause terjadi penurunan hormon estrogen di dalam tubuh sehingga terjadi risiko peningkatan kadar kolesterol total. ${ }^{25,26}$

Obesitas merupakan salah satu faktor yang mempengaruhi peningkatan kadar kolesterol total. ${ }^{27}$ Obesitas merupakan kondisi kelebihan lemak tubuh yang terakumulasi sehingga menimbulkan efek samping pada kesehatan. ${ }^{28}$ Obesitas berhubungan dengan resistensi insulin. ${ }^{29}$ Resistensi insulin pada sel lemak akan meningkatkan aktivitas lipase yang menimbulkan pemecahan trigliserida dan pelepasan asam lemak bebas ke dalam sirkulasi. ${ }^{30}$ Asam lemak bebas meningkat karena asam lemak bebas yang berasal dari lipolisis trigliserida jaringan adiposa semakin meningkat. Peningkatan asam lemak ini dapat meningkatkan resistensi insulin melalui peningkatan metabolik lemak yang mengaktifkan protein kinase C. ${ }^{31}$

Resistensi insulin berpengaruh terhadap peningkatan sintesis kolesterol dan menurunkan absorpsi kolesterol. Peningkatan sintesis kolesterol merupakan hasil dari peningkatan sintesis VLDL (very low density lipoprotein). Insulin dapat menstimulasi reseptor hati X (LXRs), yang meregulasi lipogenesis dan sintesis kolesterol melalui steroid regulatory binding protein serta meningkatkan ekspresi gen ABCG5 dan ABCG8 dalam usus yang menyebabkan penurunan absorpsi kolesterol. ${ }^{32}$

Pemberian ekstrak kacang hijau $75 \mathrm{~g} /$ hari selama 14 hari berpengaruh terhadap kadar kolesterol total. Hasil uji statistik menunjukkan terdapat perbedaan perubahan kadar kolesterol total sebelum dan sesudah intervensi $(\mathrm{p}<0,05)$. Penelitian ini sejalan dengan penelitian yang dilakukan oleh Agnes T, Palupi T dan Florida $\mathrm{H}$ menyatakan bahwa mengkonsumsi kacang hijau sebanyak 100 gr/hari dalam $300 \mathrm{ml}$ jus selama 14 hari pada wanita hiperkolesterolemia dapat menurunkan kadar kolesterol total dari $219,2 \mathrm{mg} / \mathrm{dl}$ menjadi 210,73 $\mathrm{mg} / \mathrm{dl} .^{33}$

Penurunan kadar kolesterol bisa disebabkan kandungan isoflavon yang terkandung dalam kacang hijau. Isoflavon merupakan sterol yang berasal dari tumbuhan (fitosterol) yang bertindak sebagai antioksidan dan dapat menghambat absorbsi kolesterol dari makanan maupun kolesterol yang diproduksi oleh hati. ${ }^{34,35}$ Isoflavon memiliki struktur kimia yang sama dengan estrogen yang 
dapat mempengaruhi adiposit dan jenis sel lainnya pada jaringan adiposa wanita serta berfungsi sebagai seleksi modulator reseptor estrogen pada jaringan otak dan hati yang mengatur keseimbangan energi maupun deposisi jaringan adiposa akibat perubahan metabolisme. Pengaruh lainnya pada jaringan adiposa dapat melalui mekanisme modulasi energy expenditure yang menghambat aktivitas lipoprotein lipase (LPL) yang merupakan suatu enzim yang mengatur pengambilan lemak (lipogenesis) oleh adiposit dan mempengaruhi metabolisme lemak yang dapat menurunkan kadar kolesterol. ${ }^{36,37,38}$

Genistein yang merupakan salah satu jenis isoflavon mempengaruhi liposis dengan memacu lipolytic enzyme hormone-sensitive lipase atau dengan meningkatkan efek lipolitik dari epinefrin. Mekanisme lainnya juga dapat berlangsung melalui peningkatan $\beta$-Oksidasi asam lemak yang berperan dalam pengurangan deposisi jaringan adiposa. ${ }^{38}$ Isoflavon sebagai antioksidan dengan mempengaruhi peningkatan katabolisme sel lemak pada pembentukan energi sehingga terjadi penurunan kadar kolesterol. Isoflavon dapat mengaktifkan enzim sitokrom P-450 yang mampu mengikat kolesterol menuju asam empedu, sehingga meningkatkan ekskresi asam empedu dan menurunkan kadar kolesterol darah. ${ }^{39,40}$

Rerata kadar kolesterol total masih tergolong tinggi yang juga dapat dipengaruhi oleh asupan makan. Rerata asupan serat sebelum dan sesudah intervensi pada kelompok kontrol 12,35 g. Rerata asupan serat sebelum kelompok perlakuan $11,27 \mathrm{~g}$, namun asupan serat setelah intervensi adalah 17,53 g. Asupan serat yang diasup oleh subyek berasal dari bahan makanan lainnya seperti sayuran dan buah dengan rata-rata konsumsi sayuran seperti kangkung, bayam, sawi, dll sebanyak 65,7 g/hari serta buah-buahan seperti apel, mangga, pepaya, dll sebanyak 93,3 g/hari. Sedangkan, pada kelompok perlakuan masih ditambah kacang hijau dengan kandungan serat 7,6 g/100g. Asupan serat kelompok kontrol dan perlakuan sebelum dilakukan intervensi masih tergolong kurang dari yang dianjurkan oleh American Dietetic Association (ADA), yaitu 20-35 g/hari atau berdasarkan Dietary Food and Drug Administration (FDA) setara dengan $14 \mathrm{~g} / 1000 \mathrm{kkal}^{41,42}$ Sedangkan, setelah intervensi pada kelompok perlakuan asupan serat hampir mendekati kecukupan yang dianjurkan dengan konsumsi seratnya 17,53 g.

Serat dalam makanan memiliki hubungan dengan kadar kolesterol karena berfungsi untuk mengikat lemak yang terjadi di usus dan perut. Serat membentuk gelatin dan dalam proses pencernaan mengikat asam empedu dan kolesterol selanjutnya dikeluarkan melalui feces, sehingga kadar kolesterol yang masuk ke dalam darah menurun. Proses penurunan kadar kolesterol terkait dengan fungsi hati dalam memproduksi asam empedu. Serat larut air mengikat asam empedu dan dikeluarkan melalui feces. Hal ini menyebabkan hati memproduksi lebih banyak asam empedu untuk mengganti asam empedu yang hilang. Pembentukan asam empedu memerlukan kolesterol, sehingga kolesterol akan terpakai dan tidak tertimbun di arteri dan menyebabkan kolesterol dalam darah menurun. Mekanisme lainnya yaitu penurunan absorpsi lemak dan kolesterol, penurunan laju serum insulin sehingga menurunkan rangsangan sintesis kolesterol dan lipoprotein, penghambatan sintesis kolesterol oleh asam lemak rantai pendek yang dihasilkan dari fermentasi serat larut di dalam kolon. ${ }^{43,44}$

\section{SIMPULAN}

Pemberian ekstrak kacang hijau sebanyak 75 gr/hari selama 14 hari berpengaruh terhadap penurunan kadar kolesterol total pada wanita secara signifikan.

\section{SARAN}

1. Penderita hiperkolesterolemia dapat mengkonsumsi ekstrak kacang hijau sebagai salah satu sumber isoflavon dan sebagai makanan alternatif dalam menurunkan kadar kolesterol total dengan konsumsi minimal 75 $\mathrm{g} / \mathrm{hari}$.

2. Perlu dilakukan uji kandungan isoflavon dan serat pada ekstrak kacang hijau sebelum digunakan.

3. Penelitian lebih lanjut perlu dilakukan ekstraksi isoflavon dalam kacang hijau untuk melihat pengaruh isoflavon terhadap kadar kolesterol total.

\section{DAFTAR PUSTAKA}

1. Phoebe SA, Goodwill AG, James ME, Robert. Dysfunction: International Strategies. Journal of Inflammation 2010, 7:54

2. Depkes RI. Laporan Hasil Riset Kesehatan Dasar (RISKESDAS) Nasional 2007. Jakarta: Depkes RI, 2007.

3. Depkes RI. Laporan Hasil Riset Kesehatan Dasar (RISKESDAS) Nasional 2013. Jakarta: Depkes RI, 2013.

4. Dinas Kesehatan Jawa Tengah. Buku Profil Kesehatan Provinsi Jawa Tengah. 2012. Semarang: Dinkes Jateng 2013.

5. Scheidt-Nave C, Du Y, Knopf H, Schienkiewitz A, Ziese T, Nowossadeck E, Gößwald A, Busch MA. 
Prevalence of Dyslipidemia among Adult in Germany Result of the Germany Health Interview and Examination Survey for Adults (DEG1). Bundesgesundheitsbl 2013. 56: 661-67.

6. Malazy OT, Qorbani M, Samavat T, Sharifi F, Larijani B, Fakhzadeh $H$. Prevalence of Dyslipidemia in Iran: A Systematic Review and Meta-Analysis Study. Int J Prev Med. April 2014; 5(4): 373-93.

7. Martiem M. Indeks Massa Tubuh sebagai Determinan Penyakit Jantung Koroner pada Orang Dewasa Berusia Di atas 35 Tahun. J Kedokteran Trisakti. Vol. 23 No. 3.2011.

8. Margareth R. Hubungan Merokok dengan Risiko Terjadinya Hiperkolesterolemia pada Pasien Kardiovaskuler di RS Panti Wilasa Citarum Semarang Tahun 2004. Karya Tulis Ilmiah. Universitas Diponegoro. 2004.

9. Supriyono M. Faktor-Faktor Risiko yang Berpengaruh terhadap Kejadian Penyakit Jantung Koroner pada Kelompok Usia $\leq 45$ tahun. Karya Tulis Ilmiah. Semarang. Universitas Diponegoro. 2008.

10. Lichtenstein AH, Appel LJ, Brands M, Carnethon M, Daniels S, Franch HA, et al. Diet and Lifestyle Recommendation Revision 2006: A Scientific Statement from the American Heart Association Nutrition Commitee. Circulation. 2006;114:82-96.

11. Aurora RG, Sinambela A, Noviyanti CH. Peran Konseling Berkelanjutan pada Penanganan Pasien Hiperkolesterolemia. J Indon Med Assoc, Volum: 62, Nomor 5,2012.

12. Gultekin E, Yildiz Fatih. Introduction to Phytoestrogen. In: Yildiz F. Phytoestrogen in Functional Foods $1^{\text {th }}$ Edition. Turkey: Taylor and Francis Group: 2006. 9.

13. Chao WX, Wood CM, Weder D, Aziz AS, Mehta R, Griffin P, et al. Dietary Supplementation with Soy Isoflavones or Replacement with Soy Proteins Prevents Hepatic Lipid Droplet Accumulation and Alters Expression of Genes Involved in Lipid Metabolism in Rats. Genes Nutr.2014:9:373.

14. Mittal R, Mittal N, Hota D, Suri V, Aggarwal N, Chakrabarti A. Antioxidant Effect of Isofavones: A Randomized, Double-Blind, Placebo Controlles Study in Oophorectomized Women. International Journal of Applied adn Basic Medical Research. 2004: vol 4.28-33

15. Yousef MI, Kamel KI, Esmail AM, Baghdadi HH. Antioxidant Activities and Lipid Lowering Effects of Isoflavone in Male Rabbits. Food and Chemical Toxology 42 (2004): 1497-1503.

16. Tabel Komposisi Pangan Indonesia. Persatuan Ahli Gizi Indonesia. 2009.

17. Thampson LU, Boucher BA., Zhen L, Cotterchio M, Kreiger N. Phytoestrogen Content of Foods Consumed in Canada, Including Isofavone, Lignans and Coumestan. Nutrition and Cancer, 2006;54(2):184-201
18. Harisudin M. Peluang Kacang Hijau (Phaseolus riadiatus) sebagai diet manula. Seminar Nasional Pangan Fungsional.2008.

19. Taku K, Umegaki K, Sato Y, Taki Y, Endoh K, Watanabe S. Soy Isoflavones Lower Serum Total and LDL Cholesterol in humans: a meta-analysis of 11 Ranzomized controllerd trials. Am J Clin Nutr 2007;85:1148-56.

20. Dewi NCP, Probosari E. Pengaruh Ekstrak Kacang Hijau (Phaseolus Radiatus) terhadap Kadar Kolesterol LDL Serum Tikus Hiperkolesterolemia. Journal of Nutrition Collage. Volume 2, Nomor 4, 2013

21. Seidell JC, Visscher LS. Aspek Kesehatan Masyarakat Gizi Lebih. Dalam: Gizi Kesehatan Masyarakat Edisi I. 2009. Penerbit Buku Kedokteran EGC. 203-15.

22. Direktorat Gizi Masyarakat. 2003. Petunjuk Teknis Pemantuan Status Gizi Orang Dewasa dengan Indeks Massa Tubuh (IMT). Dirjen Benkesmas. Depkes RI. Jakarta.

23. Kaplan NM. Primary Hipertension: Pathogenesis,Mechanism Of Hypertension with Obesity. In: Kaplan's Clinical Hypertension nineth edition. Philadelphia,USA: Lippincott W. 2006. 50121.

24. Galman C, Matasconi M, Persson L, Parini P, Angelin B, Rudling M. Age Induced Hypercolesterolemia in The Rat Relates to Reduced Elimination but Not Increased Intestinal Absorption of Cholesterol. American Journal of Physiology Endocrinology and Metabolism. 2007 September; 293 (3):737-42.

25. Mamat. Faktor-Faktor Yang Berhubungan Dengan Kadar Kolesterol HDL di Indonesia. FKUI;2010.

26. Soeharto I. Pengaruh Usia dan Gender terhadap Kolesterol. Dalam: Serangan Jantung dan Stroke. Jakarta : PT Gramedeia Pustaka Utama; 2004. Hal. 168-78.)

27. Listiyana AD, Mardiana, Prameswati GN. Obesitas Sentral dan Kadar Kolesterol Darah Total. Jurnal Kesehatan Masyarakat. 9(1);2013:37-43.

28. Bantas K, Agustina FMT. Risiko Hiperkolesterolemia pada Pekerja di Kawasan Industri. Kesmas Jurnal Kesehatan Masyarakat Nasional. Vol 6 No. 5, April 2012: 219-24.

29. Shoelson SE, Herrero L, Naaz A. Obesity, Inflammation, and Insulin Resistance. Gastroenterology 2007;132: 2169-80.

30. Ridwan M, Gotera W. Pengaruh Insulin terhadap Fungsi Kardiovaskular. J. Peny Dalam. Volume 10 No. 2. Mei 2009.

31. Cahjono H, Gde Budhiarta AA. Hubungan resistensi insulin dengan kadar nitric oxide pada obesitas abdominal. J Peny Dalam. Januari 2007;8(1):23-36.

32. Pihlajamaki J, Gylling H, Miettinen TA, Laakso M. Insulin resistance is associated with increased cholesterol synthesis and decreased cholesterol 
absorption in normoglycemic men. Journal of Lipid Research 2004;45:507-12.

33. Tjakrapawira A, Triwahyuni P, Hondo F. Pemanfaatan Kacang Hijau (Phaseolus Raditus Linn) untuk Menurunkan Kolesterol Total pada Wanita Hiperkolesterolemia. Prosiding Seminar Kontribusi Fisika. 2013.

34. Hapsari AI, Poernomo B, Dhamayanti Y. Perbandingan efek pemberian sari kedelai kuning dan hitam terhadap rasio kolesterol LDL/HDL darah tikus putih (Rattus norvegicus) dengan diet tinggi lemak. Artikel Ilmiah. Surabaya: FKH Universitas Airlangga; 2009.

35. Kukobo Y, Iso H, Junko I, Okada K, Inoue M, Tsugane S. Association Of Dietary Intake Osy, Beans, Isoflavones With Risk of Celebral and Myucardial Infarctions in Japanese Populations. 2007;116:2553-62.

36. Zhan D, Ho SC. Meta-analysis of The Effects of Soy Protein Containing Isoflavones on The Lipid Profile. AM J Clin Nutr 2005;81:397-408.

37. Vasanthi HR, Kartal-Ozer N, Azzi A, Das DK. Detary Supplements Cholesterol and Cardiovascular Disease. In: Nutrition and Health Fat Intakes in Disease Promotion. New York: Springer Humana Press. 2010.233.

38. Alrasyid Harun. Peranan Isoflavon Tempe Kedelai, Fokus pada Obesitas dan Komorbid. Majalah Kedokteran Nusantara Vomule 40. No.3. Sept 2007. 203-210.

39. Middleton E, Kandaswami C, Theoharides TC. The Effects of Plant Flavonoids on Mammalian Cells: Implications for Inflammation, Heart Disease, and Cancer Pharmacol Rev; 2000; 52: 673-751.

40. Tripathi MK, Kumar V, Yadav MK, Yadav D, Pandey S. Benefitial Role of Soybean Phytoestrogens. Octa Journal of Biosciences. Vol 1(2): 170-76.

41. Krummel DA. Medical Nutrition Therapy for Cardiovascular Disease. In: L. Kathleen Mahan, Sylvia Eescott-Stump, editors. Krause's Food and Nutrition Therapy. $12^{\text {th }}$ edition. Canada-Saunders Elvesier; 2008.833:6.

42. FDA. Heatlh Claim: Fruit, Vegetable and Grain Product that Countain Fiber, Particularly Soluble Fiber and Risk of Coronary Heart Disease. US. Goverment Printing Office via GPO acces. 1999;2(21): 130-33.

43. Muliawati D, Novianti S, Hidayanti. Hubungan Kebiasaan Konsumsi Serat dengan Kadar Kolesterol Total Pasien Rawat Jalan Rumah Sakit TMC Tasikmalaya 2014. Universitas Siliwangi Fakultas Kesehatan Masyarakat. 2014.

44. Prangdimurti E, Palupi NS, Zakaria FR. Metode Evaluasi Nilai Biologis Karbohidrat dan Lemak. Departemen Ilmu dan Teknologi Pangan IPB. 2007. 